\title{
Review Article \\ Clinical and Pathological Roles of Ro/SSA Autoantibody System
}

\author{
Ryusuke Yoshimi, ${ }^{1}$ Atsuhisa Ueda, ${ }^{1}$ Keiko Ozato, ${ }^{2}$ and Yoshiaki Ishigatsubo1 \\ ${ }^{1}$ Department of Internal Medicine and Clinical Immunology, Yokohama City University Graduate School of Medicine, \\ 3-9 Fukuura, Kanazawa-ku, Yokohama 236-0004, Japan \\ ${ }^{2}$ Program in Genomics of Differentiation, National Institute of Child Health and Human Development, \\ National Institutes of Health, Bethesda, MD 20892, USA \\ Correspondence should be addressed to Ryusuke Yoshimi, yoshiryu@med.yokohama-cu.ac.jp
}

Received 4 October 2012; Accepted 19 November 2012

Academic Editor: Dimitrios P. Bogdanos

Copyright (C) 2012 Ryusuke Yoshimi et al. This is an open access article distributed under the Creative Commons Attribution License, which permits unrestricted use, distribution, and reproduction in any medium, provided the original work is properly cited.

Anti-Ro/SSA antibodies are among the most frequently detected autoantibodies against extractable nuclear antigens and have been associated with systemic lupus erythematosus (SLE) and Sjögren's syndrome (SS). Although the presence of these autoantibodies is one of the criteria for the diagnosis and classification of SS, they are also sometimes seen in other systemic autoimmune diseases. In the last few decades, the knowledge of the prevalence of anti-Ro/SSA antibodies in various autoimmune diseases and symptoms has been expanded, and the clinical importance of these antibodies is increasing. Nonetheless, the pathological role of the antibodies is still poorly understood. In this paper, we summarize the milestones of the anti-Ro/SSA autoantibody system and provide new insights into the association between the autoantibodies and the pathogenesis of autoimmune diseases.

\section{Introduction}

Systemic autoimmune diseases, including systemic lupus erythematosus (SLE) and Sjögren's syndrome (SS), are a category of medical conditions that affects multiple organs and are related to autoimmune responses. These are commonly characterized by the development of autoantibodies against intracellular autoantigens. In fact, diagnosis, classification, and prognosis often rely on specificity and levels of the autoantibodies, in addition to clinical symptoms and other laboratory evaluations. Among autoantigens, extractable nuclear antigens (ENA) are soluble cytoplasmic and nuclear components with over 100 different antigens described. The main antigens used in immunological laboratories for detection are Ro, La, Sm, RNP, Scl-70, and Jo1 [1]. Anti-Ro/SSA and anti-La/SSB antibodies are among the most frequently detected autoantibodies against ENA and have traditionally been associated with SLE, SS, subacute cutaneous lupus erythematosus (SCLE), and neonatal lupus erythematosus (NLE) [2-5]. Anti-Ro/SSA and anti-La/SSB can be detected in $70-100 \%$ and $40-90 \%$, respectively, of patients with SS [6], and the presence of these autoantibodies is one of the criteria for the diagnosis and classification of SS $[7,8]$.

Anti-Ro/SSA and anti-La/SSB antibodies were originally described in 1961 as two precipitating antibodies reacting with antigens contained in extracts from salivary and lacrimal glands of patients with SS, termed $\mathrm{SjD}$, and SjT, respectively [9]. SjD antigen was reported to be insensitive to trypsin or heat, while SjT antigen could be destroyed by the same treatment. In 1969, Clark et al. described the presence of antibodies in the sera of patients with SLE that reacted with ribonucleoprotein (RNP) antigens present in extracts of rabbit and human spleen [10]. The authors named the antibody "anti-Ro antibody" after the original patient in whom the antibodies were identified. The same group also found antibodies to another soluble cytoplasmic RNA protein antigen, "La" [11]. At about the same time, Alspaugh and Tan noted the existence of autoantibodies in the sera of many SS patients, which react with antigens termed "SSA" and "SSB," [12]. SSB antigen was described also as "Ha", an antigen targeted by sera from patients with SLE and SS 
[13]. Later, Ro and La were demonstrated to be antigenically identical to SSA and SSB [14].

While anti-Ro/SSA antibodies are primarily found in patients with SLE and SS, they are also sometimes seen in other systemic autoimmune diseases, such as systemic sclerosis (SSc), polymyositis/dermatomyositis (PM/DM), mixed connective tissue disease (MCTD), and rheumatoid arthritis (RA) $[15,16]$.

Although these anti-Ro/SSA antibodies have been used as a useful diagnostic marker for SLE and SS for decades, the pathological significance of the antibodies still remains to be clarified. In this paper, we summarize the milestones of the anti-Ro/SSA autoantibodies and provide new insights into the association between the autoantibodies and autoimmune diseases.

\section{Two Autoantigens to SSA Autoantibodies, Ro52 and Ro60}

In 1981, Lerner et al. showed that the Ro antigens associate with small cytoplasmic RNAs and form Roribonucleoproteins (Ro-RNP) particles [45]. Later, Ro antigens were found to consist of two different proteins, Ro60 and Ro52. The target antigen for anti-Ro autoantibodies was first identified as a $60 \mathrm{kDa}$ protein, which exists as RNP complexes with small cytoplasmic RNAs (hY-RNA) in 1984 [46]. Subsequently, complementary DNA (cDNA) of Ro60 was cloned [47, 48]. Ben-Chetrit et al. first discovered that a $52 \mathrm{kDa}$ protein, named Ro52, was a part of the Ro antigens in 1988 [49], and three years later cDNA of human Ro52 was cloned [50, 51]. In humans, the Ro60 gene is approximately $32 \mathrm{~kb}$ in size, located on chromosome 19, while the Ro52 gene is $8.8 \mathrm{~kb}$ in size, located on chromosome 11. Although the Ro52 protein was initially suggested to be part of the RohY-RNA complex with Ro60 [49, 52, 53], subsequent studies failed to confirm a direct interaction of the proteins $[54,55]$. Recent studies provided evidence that Ro52 and Ro60 are localized to different cell compartments and that anti-Ro52 and anti-Ro60 antibodies have different clinical associations [15]. Thus it still remains unclear why autoantibodies to these two proteins are so closely linked.

Ro52 is an interferon (IFN)-inducible protein [56-64], and it is also induced by viral infection or Toll-like receptor (TLR) engagement via type I IFN induction $[59,62,65,66]$. Following the first demonstration of Ro52 ubiquitin E3 ligase activity by Wada et al. several reports supporting the conclusion have been published by other groups [57, 6770]. Recent studies, including Ro52 gene disruption studies, suggest that Ro52 is a negative regulator for proinflammatory cytokine production. Yoshimi et al. noted an increase in production of NF- $\kappa$ B-dependent cytokines, such as IL- $1 \beta$, TNF $\alpha$, and IL-6, that was observed in $R o 52^{-/-}$fibroblasts as compared to wild-type fibroblasts [62]. Data consistent with this report were published by another group [71, 72]. Another group reported that Ro52-deficient mice develop uncontrolled inflammation and systemic autoimmunity as a consequence of minor tissue injury caused by ear tagging [63]. In these mice, bone marrow-derived macrophages and splenocytes from the mutant mice released more inflammatory cytokines, IL-6, TNF $\alpha$, type I IFN, and IL-23, upon TLR activation as compared to wild type.

Several studies suggest possible associations between allelic polymorphisms of Ro52 and the disease susceptibility and increased anti-Ro52 antibodies in SLE and SS [73-76]. Furthermore, about a twofold increase in the expression of Ro52 transcripts in peripheral blood mononuclear cells (PBMC) of patients with SLE and SS as compared with healthy controls has been reported [68].

On the other hand, Ro60 antigen binds to $\sim 100 \mathrm{nt}$ noncoding RNAs called hY-RNA [45-48, 77]. It was recently reported that the Ro60 protein, having a ring shape, binds to misfolded noncoding RNAs in vertebrate nuclei and acts as a quality checkpoint for RNA misfolding with molecular chaperones for defective RNAs [78, 79]. The misfolded RNAs are targeted by Ro60 for degradation [8082]. The mice lacking the Ro60 protein develop an autoimmune syndrome characterized by autoantibody production, glomerulonephritis, and increased sensitivity to irradiation with ultraviolet light [83]. Thus, Ro60 may have a role to protect against autoimmune response.

\section{Epitopes on Ro Autoantigens}

Several studies showed that epitopes of Ro52 and Ro60 proteins have different conformational dependence [84-87]. On the Ro52 protein, most sera recognize linear epitopes in the denatured molecule, generally located in the leucine zipper site and not expressed on the surface of the native protein. In contrast, the epitopes recognized by anti-Ro60 antibodies are highly conformational and the antibodies largely lose the binding activity to the denatured protein.

Dörner et al. showed that the central region, amino acid (aa) 153-245, is the main immunogenic region of Ro52 antigen, and the strongest antigenic epitopes are located within aa 197-245 region including the leucine zipper motif [88]. Antibody responses are directed against this major antigenic region regardless of the underlying autoimmune diseases, although the strikingly different levels of antibodies and the recognition of epitopes on aa 153-196 may be related to different disease expressions. Subsequently, sera from patients with SS were found to react heterogeneously to polyubiquitylated Ro52, probably due to their different antigenic epitopes [89].

McClain et al. described that the initial epitope on Ro60, prior to clinical disease onset, includes a peptide, aa 169-180 [90]. This epitope directly cross-reacts with a peptide, aa 58 72, of the Epstein-Barr virus nuclear antigen-1 (EBNA-1). The data support the hypothesis that the Epstein-Barr virus infection had a putative triggering effect by enhancing the development of autoantibodies to Ro60 through molecular mimicry $[91,92]$.

Polyclonal class-switched anti-Ro and anti-La responses can be elicited by immunization of normal mice with recombinant La protein [93]. In this process, the production of autoantibodies to different nonoverlapping regions of La was induced. Moreover, the same immunization rapidly 
induces the production of specific Ro60 antibodies. Reciprocally, mice immunized with Ro60 protein produced anti$\mathrm{La}$ antibodies. This intra- and intermolecular spreading of autoantibody response suggests that the development of autoantibodies to multiple components of the Ro/La RNP complex may follow the initial response to a single epitope and suggest as a general explanation for the appearance of mixed autoantibody patterns in different systemic autoimmune diseases.

The accessibility of Ro/La complex for the immune system is still unknown. Based on the antigen-driven immune response hypothesis, several works suggest that it could be related to an abnormal expression on the cell surface as a consequence of UV irradiation [94-96], oxidative stress [97], TNF $\alpha$ treatment [98], viral infection [99], or estradiol treatment [100]. Another mechanism for anti-Ro and antiLa antibodies' production could be related to antigencontaining apoptotic debris during programmed cell death $[101,102]$.

\section{Anti-Ro Antibody and Demographic Feature}

Anti-Ro antibodies can be detected alone in many sera while anti-La antibodies are usually accompanied by anti-Ro antibodies. HLA class II phenotype might support epitope spreading. The presence of anti-Ro and/or anti-La antibodies is more strikingly associated with HLA-DR3 and/or HLADR2 [103, 104]. HLA-DR3 is associated with both antiRo and anti-La antibody production while HLA-DR2 favors anti-SSA antibody synthesis [105]. HLA-DQ alleles are also linked to anti-Ro and anti-La antibody responses. Both DQ1 and DQ2 alleles are associated with high concentrations of these autoantibodies [106]. The data from restriction fragment length polymorphism (RFLP) analysis also indicated that HLA-DQ alleles are related to anti-Ro antibody response [107]. In this study, all patients with anti-Ro antibodies had a glutamine residue at position 34 of the outermost domain of the DQA1 chain and/or a leucine at position 26 of the outermost domain of the DQB1 chain. Patients with both anti-Ro and -La antibodies were more likely to have all four of their DQA1/DQB1 chains containing these amino acid residues than either anti-Ro-negative SLE patients or controls. These data implicate specific amino acid residues on both DQA1 and DQB1 chains located on the floor of the antigen-binding cleft of the HLA-DQA1:B1 heterodimer.

Ro52 is an immunologically independent autoantibody system, and anti-Ro52 antibodies can exist without the presence of concomitant anti-Ro60 antibodies in systemic autoimmune diseases. Peene et al. found that anti-Ro52 antibodies are precipitin negative, not picked up by Ro enzymelinked immunosorbent assays (ELISA) based on natural Ro proteins, and have no specific antinuclear antibody (ANA) fluorescence staining pattern [108]. As a consequence, antiRo52 antibodies are frequently not detected by classical Ro detection methods, which have a bias towards antiRo60 reactivity. Moreover, Schulte-Pelkum et al. showed that anti-Ro52 and anti-Ro60 reactivities can mask each other and that more than $20 \%$ of Ro positive sera can go undetected in assays that utilize blended antigens [15]. Therefore, the authors recommended that anti-Ro52 and anti-Ro60 antibodies should be tested separately.

There exists a paper showing that the prevalence of isolated anti-Ro52 antibodies was approximately $0.5 \%$, and that detection did not lead to any significant clinical benefit as it was never the only explanation of symptoms [109]. On the other hand; several groups demonstrated the importance of separate detection of anti-Ro52 and anti-Ro60 antibodies when considering the diagnosis and, in particular, of patients with myositis $[15,41]$. In a recent study, the frequency of anti-Ro52 antibodies was similar to that of anti-Ro60 in all groups but the myositis $(35.4 \%$ versus $0.0 \%, P<0.001)$ and SSc $(19.0 \%$ versus $6.0 \%, P<0.005)$ cohorts using the consensus of three different laboratory methods [15]. In the same study, the percentages of anti-Ro52 antibodies detected without anti-Ro60 antibodies also varied from 5.4\% in childhood SLE to $35.4 \%$ in the myositis group. In the SS group, $63.2 \%$ of anti-Ro52 antibody-positive sera also had autoantibodies to Ro60.

Since Rutjes et al. found anti-Ro52 reactivity in 58\% of anti-Jo-1 antibody-positive myositis sera in 1997 [41]; several groups confirmed the data in subsequent studies $[15,110-112]$. The average coincidence of reactivity against Ro52 and Jo- 1 was $70 \%(P=0.0002$, odds ratio $=14.17, \kappa=$ 0.54 ) in anti-Jo-1 antibody-positive sera of myositis patients in a recent study [15]. These observations also suggest previous conclusions that anti-Ro52 antibody is indeed an independent autoantibody for myositis [108].

Anti-Ro52 antibodies are frequently coexpressed with antibodies to soluble liver antigen (SLA) [40, 113]. The presence of anti-Ro52 antibodies has been reported in 77$96 \%$ of patients with anti-SLA antibodies, and patients with dual antibodies had a higher frequency of HLA DRB $1 * 03$ and lower occurrence of HLA DRB1*04 than patients with anti-Ro52 antibodies alone.

\section{Anti-Ro Antibodies and Autoimmune Diseases}

Anti-Ro antibodies are the most prevalent autoantibodies among many autoimmune diseases, although their pathological role is still controversial [114]. Clinical manifestations related to anti-Ro antibodies are summarized in Table 1.

5.1. SLE and SS. Anti-Ro antibodies are frequently observed in association with SLE [115-117], SS/SLE overlap syndrome [118], SCLE [19], and NLE [25, 36, 119-122]. In contrast, anti-La antibody is more closely associated with SS. AntiRo antibodies can be detected in $70-100 \%$ and $40-90 \%$ of patients with SS and SLE, respectively, while anti-La antibodies can be detected in $35-70 \%$ and $45 \%$ of patients with SS and SLE, respectively [6]. SLE patients with C2 and C4 deficiency tend to have anti-Ro antibodies with cutaneous manifestations and polyarthritis, without renal or CNS features [116, 117, 123].

Anti-Ro and anti-La antibodies are found earlier than other SLE-related autoantibodies, such as anti-dsDNA, antiribonucleoprotein (RNP), and anti-Sm antibodies, and are 
TABLE 1: Clinical manifestations related to anti-Ro antibodies.

\begin{tabular}{|c|c|c|c|}
\hline Clinical manifestation & Disease & Ro52 specificity & Reference \\
\hline \multicolumn{4}{|l|}{ Cutaneous manifestation } \\
\hline \multirow{2}{*}{ Photosensitivity } & SLE & & {$[17]$} \\
\hline & RA & & [18] \\
\hline Subacute cutaneous lesion & SLE/SCLE & & {$[19,20]$} \\
\hline \multirow{3}{*}{ Purpura } & SLE & & {$[21,22]$} \\
\hline & SS & & {$[23,24]$} \\
\hline & RA & & {$[18]$} \\
\hline Cutaneous NLE & $\mathrm{NLE}$ & & {$[25]$} \\
\hline \multirow{3}{*}{ Sicca symptom } & SS & & {$[26]$} \\
\hline & $\mathrm{SSc}$ & & {$[27]$} \\
\hline & RA & & {$[18,28,29]$} \\
\hline Scleritis & RA & & {$[28]$} \\
\hline \multirow{3}{*}{ Interstitial lung disease } & SLE & + & {$[16,30,31]$} \\
\hline & SSc & & {$[32,33]$} \\
\hline & $\mathrm{PM} / \mathrm{DM}$ & & {$[34,35]$} \\
\hline \multicolumn{4}{|l|}{ Congenital heart disease } \\
\hline Complete heart block & NLE & & {$[25,36-38]$} \\
\hline Prolonged QT interval & NLE & & [25] \\
\hline \multicolumn{4}{|l|}{ Liver dysfunction } \\
\hline Liver function test abnormality & NLE & & {$[25]$} \\
\hline High serum bilirubin level & $\mathrm{PBC}$ & + & {$[39]$} \\
\hline \multirow{2}{*}{ Advanced histological stage } & $\mathrm{PBC}$ & + & {$[39]$} \\
\hline & AIH-1 & + & {$[40]$} \\
\hline \multicolumn{4}{|l|}{ Musculoskeletal involvement } \\
\hline Myositis & $\mathrm{PM} / \mathrm{DM}$ & + & {$[15,41,42]$} \\
\hline Arthritis & SLE & & {$[43]$} \\
\hline \multicolumn{4}{|l|}{ Hematological disorder } \\
\hline \multirow{2}{*}{ Leukopenia } & SS & & {$[23]$} \\
\hline & RA & & {$[18]$} \\
\hline Lymphopenia & SS & & {$[23]$} \\
\hline \multirow{2}{*}{ Neutropenia } & SLE & & {$[44]$} \\
\hline & NLE & & {$[25]$} \\
\hline \multirow{2}{*}{ Anemia } & NLE & & {$[25]$} \\
\hline & RA & & [29] \\
\hline Thrombocytopenia & NLE & & {$[25]$} \\
\hline \multicolumn{4}{|l|}{ Immunological disorder } \\
\hline Hypocomplementemia & RA & & {$[18]$} \\
\hline \multirow{2}{*}{ High serum IgG level } & SS & & {$[23]$} \\
\hline & RA & & {$[28]$} \\
\hline High serum IgM level & $\mathrm{PBC}$ & + & [39] \\
\hline
\end{tabular}

SLE: systemic lupus erythematosus; RA: rheumatoid arthritis; SCLE: subacute cutaneous lupus erythematosus; SS: Sjögren's syndrome; NLE: neonatal lupus erythematosus; SSc: systemic sclerosis; PM: polymyositis; DM: dermatomyositis; PBC: primary biliary cirrhosis; AIH-1: type 1 autoimmune hepatitis.

present, on average, 3.4 years before the diagnosis of SLE [124]. Another paper also shows that the autoantibody type that appears first before the onset of symptoms is antiRo antibodies that appear at a mean of 6.6 years [125]. Some groups suggest a close association between anti-Ro antibodies and late onset SLE, with the onset of symptoms after the age of $50[20,126]$. There are conflicting data as to the correlation of anti-Ro antibody titers with disease activity during the course of SLE and SS [127-131].

Anti-Ro antibodies have been reported to be associated with photosensitivity, SCLE, cutaneous vasculitis (palpable purpura), and hematological disorder (anemia, leukopenia, 
and thrombocytopenia) $[17,19,21,22,44,132]$. Interstitial pneumonitis has been also closely associated with anti-Ro antibodies in patients with SLE, but there is so far no evidence of a direct involvement of the antibodies in the pathogenesis of the pulmonary disease $[16,20,30,31]$. The relationship between anti-Ro antibodies and nonerosive deforming arthritis, called Jaccoud's arthropathy, has been reported $[43,133]$.

In SS, anti-Ro, and anti-La antibodies are present in the lacrimal fluid of some patients and their presence in serum or lacrimal fluid is associated with the severity of keratoconjunctivitis sicca [26]. High titers of anti-Ro and anti-La antibodies also have been shown to be associated with a greater incidence of extraglandular manifestations, especially purpura, leukopenia, and lymphopenia $[23,24]$.

5.2. NLE. NLE is a passively transferred autoimmune disease that occurs in some babies born to mothers with antiRo and/or anti-La antibodies [120, 134]. The most serious complication in the neonate is congenital complete heart block (CHB), which occurs in 1-5\% of such pregnancies and $6-25 \%$ of subsequent pregnancies with a previously affected child with $\mathrm{CHB}$ [37].

Since the 1950s, it was recognized that maternal autoantibodies can cross the placenta and that fetuses of mothers with an autoimmune disease may develop isolated congenital complete atrioventricular block that has been already recognized as a distinct clinical entity $[38,135]$. In the early 1980s, a close association between maternal anti-Ro and antiLa antibodies and CHB was shown $[36,136,137]$.

Other features of NLE are frequently observed after birth and include cutaneous rash, hematological disorder (thrombocytopenia, leukopenia, and anemia), and liver dysfunction [25]. Unlike CHB, these symptoms of NLE usually resolve within 6 months after birth, coincident with the time of the clearance of the maternal antibodies from the infants' circulation.

A recent paper described that all cardiac complications seen in neonates were associated with moderate to high $(\geq 50 \mathrm{U} / \mathrm{mL})$ maternal anti-Ro antibody levels, independently of anti-La antibody titers [38]. The event rate of $\mathrm{CHB}$ was $5 \%$ for prospectively screened fetuses with high anti-Ro antibody levels ( $\geq 50 \mathrm{U} / \mathrm{mL}$; odds ratio: 7.8 ) and $0 \%$ for those exposed to lower titers. On the other hand, infants with prenatal exposure to high titers of anti-La antibodies $(\geq 100 \mathrm{U} / \mathrm{mL}$ ) were most likely to have noncardiac manifestations of NLE, with an event rate of $57 \%$ (odds ratio: 4.7). These findings suggest that the concentration of maternal autoantibodies, rather than their presence, is associated with the development of NLE. Thus fetal echocardiography should be reserved for women with high anti-Ro antibody titers [38].

As most mothers of neonates with NLE do not have any connective tissue disease, a previous suggestion that all pregnant women should be screened for anti-Ro antibodies irrespective of their symptoms or clinical status may be considered reasonable [138].
5.3. Other Autoimmune Diseases. Anti-Ro antibodies are found also in 3-11\% of patients with SSc [15, 27, 32, 139] and associated with sicca symptoms and severe pulmonary involvement [27, 32, 33]. Anti-Ro antibodies are detectable in $5-15 \%$ of patients affected by idiopathic inflammatory myopathy, including polymyositis (PM) and dermatomyositis (DM). PM/DM patients with anti-Ro antibodies frequently showed a specific reactivity to Ro52 without Ro60 $[15,41,42,140]$. The presence of anti-Ro52 antibodies is associated with anti-Jo-1 antibodies or other anti-aminoacyl transfer RNA synthetase (ARS) antibodies [15, 41, 140-142]. The coexistence of anti-Ro and anti-Jo-1 antibodies seems to be related to a more severe interstitial lung disease compared with the patients with anti-Jo-1 antibodies alone $[34,35]$.

Anti-Ro antibodies are detected in $3-15 \%$ of patients with RA [28, 29, 143]. Most RA patients with anti-Ro antibodies share the same extra-articular features, such as sicca, photosensitivity, purpura, leukopenia, anemia, and hypocomplementemia $[18,28,29]$. Some authors also have mentioned a strong association between anti-Ro antibodies and the development of side effects by treatment with gold salts or D-penicillamine [144-146]. In a recent report antiRo antibodies are suggested to be an independent factor associated with an insufficient response to tumor necrosis factor (TNF) inhibitors in patients with RA [147].

Anti-Ro52 antibodies have a high specificity in primary biliary cirrhosis (PBC), an autoimmune liver disease. They are found in $28 \%$ of patients with $\mathrm{PBC}$ and in a more advanced histological stage [39]. Higher serum bilirubin and IgM levels at the time of diagnosis are related to antiRo52 antibodies. Antibodies to Ro52 are also detected in $38 \%$ of patients with type 1 autoimmune hepatitis, and they, together with anti-SLA antibodies, are independently associated with the development of cirrhosis and hepatic death or liver transplantation [40].

\section{Pathogenic Role of Anti-Ro Antibodies}

Although the pathogenic role of autoantibodies in autoimmune disease has not yet been clarified, hypotheses have been put forward indicating that anti-Ro antibodies might have a direct role in damaging tissues. UV irradiation induces de novo synthesis of the Ro antigens in both the cytoplasm and the nucleus in keratinocytes [96]. Besides, UV irradiation increases the expression of the antigens on the cell surface $[94,96]$, enhancing the possibility of direct injury of keratinocytes by anti-Ro antibodies [95]. Based on the data, Norris developed a hypothetical model of the pathogenesis of photosensitivity [148]. (1) UV exposure leads to an increased synthesis and expression of Ro antigen on the surface of epidermal keratinocytes; (2) anti-Ro antibodies from the circulation bind to the antigens on the cell surface; (3) the Fc domains of the bound anti-Ro antibodies are recognized by lymphocytes, leading to keratinocyte death. This hypothesis was consistent with the following study showing that photosensitivity and titer of circulating antiRo/anti-La antibodies were directly correlated with the expression of Ro and La antigens in skin specimens of 
patients with SLE [149]. However, patients with SS and SLE with anti-Ro and/or anti-La antibodies only infrequently show photosensitivity [150].

Additional evidence for a direct pathogenic role of antiRo and anti-La can be found in studies of NLE. The cardiac damage is related to the expression of Ro and La antigens in fetal cardiac tissue from the 18th to 24th week, particularly located on the surface of cardiac myocytes [151-153]. Previous studies demonstrated that binding of anti-Ro and/or anti-La antibodies to apoptotic cardiocytes impairs their removal by healthy cardiocytes during the physiological cell deletion process in embryogenesis [154]. It also increases urokinase plasminogen activator- (uPA-)/uPA receptor- (uPAR-) dependent plasminogen and TGF- $\beta$ activation $[155,156]$. Again, it is still unclear why NLE develops in only some but not all antibody-exposed fetuses.

Interestingly, some anti-Ro antibody-positive adult patients with connective tissue disease may have disturbances in cardiac repolarization. Significantly increased mean corrected QT (QTc) intervals were present among anti-Ro antibody-positive patients when compared to antiRo antibody-negative individuals $[157,158]$. The prolonged QTc interval seems to be directly attributable to the electrophysiological interference of anti-Ro antibodies with the inhibition of the I $\kappa \mathrm{r}$ current in cardiac myocytes [159]. Ventricular arrhythmias may also be more prevalent in those with anti-Ro antibodies [160].

Is there any possibility for anti-Ro antibodies to meet with Ro antigens inside the cell? Recently, it has been reported that IgG can enter the cytoplasm of nonimmune cells through the cell membrane together with virus [161]. In this paper, Ro52 acts as a cytosolic IgG receptor; it rapidly recruits incoming antibody-bound virus and targets it to the proteasomal degradation via its E3 ubiquitin ligase activity. This suggests the possibility of intracellular autoantigen-autoantibody interaction. A recent report shows that anti-Ro52 antibodies inhibit the E3 ligase activity of Ro52 by sterically blocking the E2/E3 interaction between Ro52 and UBE2E1 [162]. Although it still remains to be investigated whether enough anti-Ro52 autoantibodies can enter cells to sufficiently inhibit Ro52 function as a negative proinflammatory cytokine regulator, this inhibition may contribute to the pathogenesis of SLE and SS by inhibiting Ro52-mediated ubiquitylation.

\section{Conclusions}

Although anti-Ro antibodies have been used as a useful diagnostic marker for SLE and SS, they are the most prevalent autoantibodies among various autoimmune diseases. Above all, anti-Ro52 antibodies are specifically associated with myositis, SSc, and PBC. Furthermore, anti-Ro52 antibodies are related to a variety of symptoms in autoimmune diseases. Thus, separate measurement of anti-Ro52 and anti-Ro60 antibodies should be clinically useful. Anti-Ro52 antibodies may have pathological roles not only by damaging tissues directly but also by inhibiting the activity of Ro52 antigens. Further investigations into the Ro autoantigen-autoantibody system may offer a new strategy for treating autoimmune diseases.

\section{Conflict of Interests}

The authors have no financial conflict of interests.

\section{Acknowledgments}

The authors thank Mr. Tom Kiper for his review of the paper. This work was supported by research Grants from Japan Society for the Promotion of Science KAKENHI (no. 23791118) (R. Yoshimi) and Kanagawa Nanbyo Study Foundation (R. Yoshimi). This work was also supported partly by the Intramural Program of NICHD, National Institutes of Health, USA.

\section{References}

[1] H. E. Prince and W. R. Hogrefe, "Evaluation of a line immunoblot assay for detection of antibodies recognizing extractable nuclear antigens," Journal of Clinical Laboratory Analysis, vol. 12, no. 5, pp. 320-324, 1998.

[2] E. K. L. Chan and L. E. C. Andrade, "Antinuclear antibodies in Sjogren's syndrome," Rheumatic Disease Clinics of North America, vol. 18, no. 3, pp. 551-570, 1992.

[3] C. A. von Muhlen and E. M. Tan, "Autoantibodies in the diagnosis of systemic rheumatic diseases," Seminars in Arthritis and Rheumatism, vol. 24, no. 5, pp. 323-358, 1995.

[4] K. Yamamoto, "Pathogenesis of Sjogren's syndrome," Autoimmunity Reviews, vol. 2, no. 1, pp. 13-18, 2003.

[5] R. Kobayashi, S. Mii, T. Nakano, H. Harada, and H. Eto, "Neonatal lupus erythematosus in Japan: a review of the literature," Autoimmunity Reviews, vol. 8, no. 6, pp. 462-466, 2009.

[6] J. Wenzel, R. Gerdsen, M. Uerlich, R. Bauer, T. Bieber, and I. Boehm, "Antibodies targeting extractable nuclear antigens: historical development and current knowledge," British Journal of Dermatology, vol. 145, no. 6, pp. 859-867, 2001.

[7] C. Vitali, S. Bombardieri, R. Jonsson et al., "Classification criteria for Sjögren's syndrome: a revised version of the European criteria proposed by the American-European consensus group," Annals of the Rheumatic Diseases, vol. 61, no. 6, pp. 554-558, 2002.

[8] S. C. Shiboski, C. H. Shiboski, L. Criswell et al., "American College of Rheumatology classification criteria for Sjogren's syndrome: a data-driven, expert consensus approach in the Sjogren's International Collaborative Clinical Alliance cohort," Arthritis Care and Research, vol. 64, no. 4, pp. 475487, 2012.

[9] J. R. Anderson, K. Gray, J. S. Beck, and W. F. Kinnear, "Precipitating autoantibodies in Sjogren's disease," The Lancet, vol. 278, no. 7200, pp. 456-460, 1961.

[10] G. Clark, M. Reichlin, and T. B. Tomasi Jr., "Characterization of a soluble cytoplasmic antigen reactive with sera from patients with systemic lupus erythmatosus," The Journal of Immunology, vol. 102, no. 1, pp. 117-122, 1969.

[11] M. Mattioli and M. Reichlin, "Heterogeneity of RNA protein antigens reactive with sera of patients with systemic lupus erythematosus. Description of a cytoplasmic nonribosomal 
antigen," Arthritis and Rheumatism, vol. 17, no. 4, pp. 421429, 1974.

[12] M. A. Alspaugh and E. M. Tan, "Antibodies to cellular antigens in Sjogren's syndrome," The Journal of Clinical Investigation, vol. 55, no. 5, pp. 1067-1073, 1975.

[13] M. Akizuki, R. Powers, and H. R. Holman, "A soluble acidic protein of the cell nucleus which reacts with serum from patients with systemic lupus erythematosus and Sjogren's syndrome," The Journal of Clinical Investigation, vol. 59, no. 2, pp. 264-272, 1977.

[14] M. Alspaugh and P. Maddison, "Resolution of the identity of certain antigen-antibody systems in systemic lupus erythematosus and Sjogren's syndrome: an interlaboratory collaboration," Arthritis and Rheumatism, vol. 22, no. 7, pp. 796-798, 1979.

[15] J. Schulte-Pelkum, M. Fritzler, and M. Mahler, "Latest update on the Ro/SS-a autoantibody system," Autoimmunity Reviews, vol. 8, no. 7, pp. 632-637, 2009.

[16] P. Ghillani, C. André, C. Toly et al., "Clinical significance of anti-Ro52 (TRIM21) antibodies non-associated with antiSSA 60kDa antibodies: results of a multicentric study," Autoimmunity Reviews, vol. 10, no. 9, pp. 509-513, 2011.

[17] C. B. Mond, M. G. E. Peterson, and N. F. Rothfield, "Correlation of anti-Ro antibody with photosensitivity rash in systemic lupus erythematosus patients," Arthritis and Rheumatism, vol. 32, no. 2, pp. 202-204, 1989.

[18] G. Boire, H. A. Menard, M. Gendron, A. Lussier, and D. Myhal, "Rheumatoid arthritis: anti-Ro antibodies define a non-HLA-DR4 associated clinicoserological cluster," The Journal of Rheumatology, vol. 20, no. 10, pp. 1654-1660, 1993.

[19] D. P. McCauliffe, "Cutaneous diseases in adults associated with Anti-Ro/SS-A autoantibody production,” Lupus, vol. 6, no. 2, pp. 158-166, 1997.

[20] M. C. Hochberg, R. E. Boyd, and J. M. Ahearn, "Systemic lupus erythematosus: a review of clinico-laboratory features and immunogenetic markers in 150 patients with emphasis on demographic subsets," Medicine, vol. 64, no. 5, pp. 285295, 1985.

[21] M. V. Fukuda, S. C. Lo, C. S. de Almeida, and S. K. Shinjo, "Anti-Ro antibody and cutaneous vasculitis in systemic lupus erythematosus," Clinical Rheumatology, vol. 28, no. 3, pp. 301-304, 2009.

[22] E. L. Alexander, F. C. Arnett Jr., T. T. Provost, and M. B. Stevens, "Sjogren's syndrome: association of anti-Ro(SS-A) antibodies with vasculitis, hematologic abnormalities, and serologic hyperreactivity," Annals of Internal Medicine, vol. 98, no. 2, pp. 155-159, 1983.

[23] J. B. Harley, E. L. Alexander, W. B. Bias et al., "Anti-Ro (SSA) and anti-La (SS-B) in patients with Sjogren's syndrome," Arthritis and Rheumatism, vol. 29, no. 2, pp. 196-206, 1986.

[24] J. K. Chung, M. K. Kim, and W. R. Wee, "Prognostic factors for the clinical severity of keratoconjunctivitis sicca in patients with Sjogren's syndrome," British Journal of Ophthalmology, vol. 96, no. 2, pp. 240-245, 2012.

[25] R. Cimaz, D. L. Spence, L. Hornberger, and E. D. Silverman, "Incidence and spectrum of neonatal lupus erythematosus: a prospective study of infants born to mothers with anti-ro autoantibodies," Journal of Pediatrics, vol. 142, no. 6, pp. 678683, 2003.

[26] E. Toker, S. Yavuz, and H. Direskeneli, "Anti-Ro/SSA and anti-La/SSB autoantibodies in the tear fluid of patients with Sjogren's syndrome," British Journal of Ophthalmology, vol. 88, no. 3, pp. 384-387, 2004.
[27] A. A. Drosos, A. P. Andonopoulos, J. S. Costopoulos, E. D. Stavropoulos, C. S. Papadimitriou, and M. Moutsopoulos, "Sjogren's syndrome in progressive systemic sclerosis," The Journal of Rheumatology, vol. 15, no. 6, pp. 965-968, 1988.

[28] I. Cavazzana, F. Franceschini, M. Quinzanini et al., "AntiRo/SSA antibodies in rheumatoid arthritis: clinical and immunologic associations," Clinical and Experimental Rheumatology, vol. 24, no. 1, pp. 59-64, 2006.

[29] F. N. Skopouli, A. P. Andonopoulos, and H. M. Moutsopoulos, "Clinical implications of the presence of anti-Ro(SSA) antibodies in patients with rheumatoid arthritis," Journal of Autoimmunity, vol. 1, no. 4, pp. 381-388, 1988.

[30] M. T. Hedgpeth and D. W. Boulware, "Interstitial pneumonitis in antinuclear antibody-negative systemic lupus erythematosus: a new clinical manifestation and possible association with anti-Ro (SS-A) antibodies," Arthritis and Rheumatism, vol. 31, no. 4, pp. 545-548, 1988.

[31] T. T. Provost, R. Watson, and E. Simmons-O'Brien, “AntiRo(SS-A) antibody positive Sjogren's/lupus erythematosus overlap syndrome,” Lupus, vol. 6, no. 2, pp. 105-111, 1997.

[32] A. Parodi, P. Puiatti, and A. Rebora, "Serological profiles as prognostic clues for progressive systemic scleroderma: the Italian experience," Dermatologica, vol. 183, no. 1, pp. 15-20, 1991.

[33] S. N. Breit, D. Cairns, A. Szentirmay et al., "The presence of Sjogren's syndrome is a major determinant of the pattern of interstitial lung disease in scleroderma and other connective tissue diseases," The Journal of Rheumatology, vol. 16, no. 8, pp. 1043-1049, 1989.

[34] A. Vancsa, I. Csipo, J. Nemeth, K. Devenyi, L. Gergely, and K. Danko, "Characteristics of interstitial lung disease in SSA positive/Jo-1 positive inflammatory myopathy patients," Rheumatology International, vol. 29, no. 9, pp. 989-994, 2009.

[35] R. La Corte, A. Lo Mo Naco, A. Locaputo, F. Dolzani, and F. Trotta, "In patients with antisynthetase syndrome the occurrence of anti-Ro/SSA antibodies causes a more severe interstitial lung disease," Autoimmunity, vol. 39, no. 3, pp. 249-253, 2006.

[36] J. P. Buyon, E. Ben-Chetrit, S. Karp et al., "Acquired congenital heart block. Pattern of maternal antibody response to biochemically defined antigens of the SSA/Ro-SSB/La system in neonatal lupus," The Journal of Clinical Investigation, vol. 84, no. 2, pp. 627-634, 1989.

[37] A. Brucato, M. Frassi, F. Franceschini et al., "Risk of congenital complete heart block in newborns of mothers with anti-Ro/SSA antibodies detected by counterimmunoelectrophoresis: a prospective study of 100 women," Arthritis and Rheumatism, vol. 44, no. 8, pp. 1832-1835, 1832.

[38] E. Jaeggi, C. Laskin, R. Hamilton, J. Kingdom, and E. Silverman, "The importance of the level of maternal Anti-Ro/SSA antibodies as a prognostic marker of the development of cardiac neonatal lupus erythematosus. A prospective study of 186 antibody-exposed fetuses and infants," Journal of the American College of Cardiology, vol. 55, no. 24, pp. 27782784, 2010.

[39] A. Granito, P. Muratori, L. Muratori et al., "Antibodies to SS$\mathrm{A} / \mathrm{Ro}-52 \mathrm{kD}$ and centromere in autoimmune liver disease: a clue to diagnosis and prognosis of primary biliary cirrhosis," Alimentary Pharmacology and Therapeutics, vol. 26, no. 6, pp. 831-838, 2007.

[40] A. J. Montano-Loza, Z. Shums, G. L. Norman, and A. J. Czaja, "Prognostic implications of antibodies to Ro/SSA and soluble liver antigen in type 1 autoimmune hepatitis," Liver International, vol. 32, no. 1, pp. 85-92, 2012. 
[41] S. A. Rutjes, W. T. M. Vree Egberts, P. Jongen, F. Van Den Hoogen, G. J. M. Pruijn, and W. J. Van Venrooij, "Anti-Ro52 antibodies frequently co-occur with anti-Jo-1 antibodies in sera from patients with idiopathic inflammatory myopathy," Clinical and Experimental Immunology, vol. 109, no. 1, pp. 32-40, 1997.

[42] M. Kubo, H. Ihn, Y. Asano, K. Yamane, N. Yazawa, and K. Tamaki, "Prevalence of 52-kd and 60-kd Ro/SS-A autoantibodies in Japanese patients with polymyositis/dermatomyositis," Journal of the American Academy of Dermatology, vol. 47, no. 1, pp. 148-151, 2002.

[43] F. Franceschini, L. Cretti, M. Quinzanini, F. L. Rizzini, and R. Cattaneo, "Deforming arthropathy of the hands in systemic lupus erythematosus is associated with antibodies to SSA/Ro and to SSB/La," Lupus, vol. 3, no. 5, pp. 419-422, 1994.

[44] B. T. Kurien, J. Newland, C. Paczkowski, K. L. Moore, and R. H. Scofield, "Association of neutropenia in systemic lupus erythematosus (SLE) with anti-Ro and binding of an immunologically cross-reactive neutrophil membrane antigen," Clinical and Experimental Immunology, vol. 120, no. 1, pp. 209-217, 2000.

[45] M. R. Lerner, J. A. Boyle, J. A. Hardin, and J. A. Steitz, "Two novel classes of small ribonucleoproteins detected by antibodies associated with lupus erythematosus," Science, vol. 211, no. 4480, pp. 400-402, 1981.

[46] S. L. Wolin and J. A. Steitz, "The Ro small cytoplasmic ribonucleoproteins: Identification of the antigenic protein and its binding site on the Ro RNAs," Proceedings of the National Academy of Sciences of the United States of America, vol. 81, no. 7 I, pp. 1996-2000, 1984.

[47] E. Ben-Chetrit, B. J. Gandy, E. M. Tan, and K. F. Sullivan, "Isolation and characterization of a cDNA clone encoding the $60-\mathrm{kD}$ component of the human SS-A/Ro ribonucleoprotein autoantigen," The Journal of Clinical Investigation, vol. 83, no. 4, pp. 1284-1292, 1989.

[48] S. L. Deutscher, J. B. Harley, and J. D. Keene, "Molecular analysis of the $60-\mathrm{kDa}$ human Ro ribonucleoprotein," Proceedings of the National Academy of Sciences of the United States of America, vol. 85, no. 24, pp. 9479-9483, 1988.

[49] E. Ben-Chetrit, E. K. L. Chan, K. F. Sullivan, and E. M. Tan, "A $52-\mathrm{kD}$ protein is a novel component of the SS-A/Ro antigenic particle," Journal of Experimental Medicine, vol. 167, no. 5, pp. 1560-1571, 1988.

[50] E. K. L. Chan, J. C. Hamel, J. P. Buyon, and E. M. Tan, "Molecular definition and sequence motifs of the $52-\mathrm{kD}$ component of human SS-A/Ro autoantigen," The Journal of Clinical Investigation, vol. 87, no. 1, pp. 68-76, 1991.

[51] K. Itoh, Y. Itoh, and M. B. Frank, "Protein heterogeneity in the human Ro/SSA ribonucleoproteins. The 52- and $60-\mathrm{kD}$ Ro/SSA autoantigens are encoded by separate genes," The Journal of Clinical Investigation, vol. 87, no. 1, pp. 177-186, 1991.

[52] R. L. Slobbe, W. Pluk, W. J. Van Venrooij, and G. J. M. Pruijn, "Ro ribonucleoprotein assembly in vitro identification of RNA-protein and protein-protein interactions," Journal of Molecular Biology, vol. 227, no. 2, pp. 361-366, 1992.

[53] B. T. Kurien, T. L. Chambers, P. Y. Thomas, M. B. Frank, and R. H. Scofield, "Autoantibody to the leucine zipper region of $52 \mathrm{kDa}$ Ro/SSA binds native $60 \mathrm{kDa}$ Ro/SSA: identification of a tertiary epitope with components from $60 \mathrm{kDA}$ Ro/SSA and $52 \mathrm{kDa}$ Ro/SSA," Scandinavian Journal of Immunology, vol. 53, no. 3, pp. 268-276, 2001.
[54] G. Boire, M. Gendron, N. Monast, B. Bastin, and H. A. Menard, "Purification of antigenically intact Ro ribonucleoproteins; biochemical and immunological evidence that the $52-\mathrm{kD}$ protein is not a Ro protein," Clinical and Experimental Immunology, vol. 100, no. 3, pp. 489-498, 1995.

[55] A. Kelekar, M. R. Saitta, and J. D. Keene, "Molecular composition of Ro small ribonucleoprotein complexes in human cells. Intracellular localization of the $60-$ and $52-\mathrm{kD}$ proteins," The Journal of Clinical Investigation, vol. 93, no. 4, pp. 1637-1644, 1994.

[56] D. A. Rhodes, G. Ihrke, A. T. Reinicke et al., "The 52000 MW Ro/SS-A autoantigen in Sjögren's syndrome/systemic lupus erythematosus (Ro52) is an interferon- $\gamma$ inducible tripartite motif protein associated with membrane proximal structures," Immunology, vol. 106, no. 2, pp. 246-256, 2002.

[57] H.J. Kong, D. E. Anderson, C. H. Lee et al., "Cutting edge: autoantigen Ro52 is an interferon inducible E3 ligase that ubiquitinates IRF-8 and enhances cytokine expression in macrophages," The Journal of Immunology, vol. 179, no. 1, pp. 26-30, 2007.

[58] S. D. Der, A. Zhou, B. R. G. Williams, and R. H. Silverman, "Identification of genes differentially regulated by interferon $\alpha, \beta$, or $\gamma$ using oligonucleotide arrays," Proceedings of the National Academy of Sciences of the United States of America, vol. 95, no. 26, pp. 15623-15628, 1998.

[59] L. Strandberg, A. Ambrosi, A. Espinosa et al., "Interferon- $\alpha$ induces up-regulation and nuclear translocation of the Ro52 autoantigen as detected by a panel of novel Ro52-specific monoclonal antibodies," Journal of Clinical Immunology, vol. 28, no. 3, pp. 220-231, 2008.

[60] G. K. Geiss, M. Salvatore, T. M. Tumpey et al., "Cellular transcriptional profiling in influenza a virus-infected lung epithelial cells: the role of the nonstructural NS1 protein in the evasion of the host innate defense and its potential contribution to pandemic influenza," Proceedings of the National Academy of Sciences of the United States of America, vol. 99, no. 16, pp. 10736-10741, 2002.

[61] J. M. Zimmerer, G. B. Lesinski, M. D. Radmacher, A. Ruppert, and W. E. Carson, "STAT1-dependent and STAT1independent gene expression in murine immune cells following stimulation with interferon-alpha," Cancer Immunology, Immunotherapy, vol. 56, no. 11, pp. 1845-1852, 2007.

[62] R. Yoshimi, T. H. Chang, H. Wang, T. Atsumi, H. C. Morse III, and K. Ozato, "Gene disruption study reveals a nonredundant role for TRIM21/Ro52 in NF- $\kappa$ B-dependent cytokine expression in fibroblasts," The Journal of Immunology, vol. 182, no. 12, pp. 7527-7538, 2009.

[63] A. Espinosa, V. Dardalhon, S. Brauner et al., "Loss of the lupus autoantigen Ro52/Trim21 induces tissue inflammation and systemic autoimmunity by disregulating the IL-23-Th17 pathway," Journal of Experimental Medicine, vol. 206, no. 8, pp. 1661-1671, 2009.

[64] R. Yoshimi, Y. Ishigatsubo, and K. Ozato, "Autoantigen TRIM21/Ro52 as a possible target for treatment of systemic lupus erythematosus," International Journal of Rheumatology, vol. 2012, Article ID 718237, 11 pages, 2012.

[65] R. Rajsbaum, J. P. Stoye, and A. O'Garra, “Type I interferondependent and -independent expression of tripartite motif proteins in immune cells," European Journal of Immunology, vol. 38, no. 3, pp. 619-630, 2008.

[66] K. Ozato, D. M. Shin, T. H. Chang, and H. C. Morse III, "TRIM family proteins and their emerging roles in innate 
immunity," Nature Reviews Immunology, vol. 8, no. 11, pp. 849-860, 2008.

[67] K. Wada and T. Kamitani, "Autoantigen Ro52 is an E3 ubiquitin ligase," Biochemical and Biophysical Research Communications, vol. 339, no. 1, pp. 415-421, 2006.

[68] A. Espinosa, W. Zhou, M. Ek et al., “The Sjögren’s syndromeassociated autoantigen Ro52 is an E3 ligase that regulates proliferation and cell death," The Journal of Immunology, vol. 176 , no. 10, pp. 6277-6285, 2006.

[69] A. Sabile, A. M. Meyer, C. Wirbelauer et al., "Regulation of p27 degradation and S-phase progression by Ro52 RING finger protein," Molecular and Cellular Biology, vol. 26, no. 16, pp. 5994-6004, 2006.

[70] J. Y. Kim and K. Ozato, "The sequestosome 1/p62 attenuates cytokine gene expression in activated macrophages by inhibiting IFN regulatory factor 8 and TNF receptorassociated factor $6 / \mathrm{NF}-\kappa \mathrm{B}$ activity," The Journal of Immunology, vol. 182, no. 4, pp. 2131-2140, 2009.

[71] K. Wada, M. Niida, M. Tanaka, and T. Kamitani, "Ro52mediated monoubiquitination of IKK $\beta$ down-regulates NF$\kappa \mathrm{B}$ signalling," Journal of Biochemistry, vol. 146, no. 6, pp. 821-832, 2009.

[72] M. Niida, M. Tanaka, and T. Kamitani, "Downregulation of active IKK $\beta$ by Ro52-mediated autophagy," Molecular Immunology, vol. 47, no. 14, pp. 2378-2387, 2010.

[73] M. B. Frank, K. Itoh, A. Fujisaku, P. Pontarotti, M. G. Mattei, and B. R. Neas, "The mapping of the human $52-\mathrm{kD}$ Ro/SSA autoantigen gene to human chromosome II, and its polymorphisms," American Journal of Human Genetics, vol. 52, no. 1, pp. 183-191, 1993.

[74] H. Tsugu, R. Horowitz, N. Gibson, and M. B. Frank, "The location of a disease-associated polymorphism and genomic structure of the human $52-\mathrm{kDa}$ Ro/SSA locus (SSA1)," Genomics, vol. 24, no. 3, pp. 541-548, 1994.

[75] B. Nakken, R. Jonsson, and A. I. Bolstad, "Polymorphisms of the Ro52 gene associated with anti-Ro 52-kd autoantibodies in patients with primary Sjogren's syndrome," Arthritis \& Rheumatism, vol. 44, no. 3, pp. 638-646, 2001.

[76] T. Imanishi, A. Morinobu, N. Hayashi et al., "A novel polymorphism of the SSA1 gene is associated with antiSS-A/Ro52 autoantibody in Japanese patients with primary Sjögren's syndrome," Clinical and Experimental Rheumatology, vol. 23, no. 4, pp. 521-524, 2005.

[77] J. P. Hendrick, S. L. Wolin, J. Rinke, M. R. Lerner, and J. A. Steitz, "Ro small cytoplasmic ribonucleoproteins are a subclass of La ribonucleoproteins: further characterization of the Ro and La small ribonucleoproteins from uninfected mammalian cells," Molecular and Cellular Biology, vol. 1, no. 12, pp. 1138-1149, 1981.

[78] C. D. Green, K. S. Long, H. Shi, and S. L. Wolin, "Binding of the 60-kDA Ro autoantigen to Y RNAs: evidence for recognition in the major groove of a conserved helix," RNA, vol. 4, no. 7, pp. 750-765, 1998.

[79] A. Belisova, K. Semrad, O. Mayer et al., "RNA chaperone activity of protein components of human Ro RNPs," RNA, vol. 11, no. 7, pp. 1084-1094, 2005.

[80] S. L. Wolin and K. M. Reinisch, “The Ro $60 \mathrm{kDa}$ autoantigen comes into focus: Interpreting epitope mapping experiments on the basis of structure," Autoimmunity Reviews, vol. 5, no. 6, pp. 367-372, 2006.

[81] C. A. O'Brien and S. L. Wolin, "A possible role for the $60-\mathrm{kD}$ Ro autoantigen in a discard pathway for defective 5S rRNA precursors," Genes and Development, vol. 8, no. 23, pp. 28912903, 1994.
[82] X. Chen, J. D. Smith, H. Shi, D. D. Yang, R. A. Flavell, and S. L. Wolin, "The Ro autoantigen binds misfolded U2 small nuclear RNAs and assists mammalian cell survival after UV irradiation," Current Biology, vol. 13, no. 24, pp. 2206-2211, 2003.

[83] D. Xue, H. Shi, J. D. Smith et al., "A lupus-like syndrome develops in mice lacking the Ro $60-\mathrm{kDa}$ protein, a major lupus autoantigen," Proceedings of the National Academy of Sciences of the United States of America, vol. 100, no. 13, pp. 7503-7508, 2003.

[84] Y. Itoh and M. Reichlin, "Autoantibodies to the Ro/SSA antigen are conformation dependent. I: anti-60 kD antibodies are mainly directed to the native protein; anti-52 $\mathrm{kD}$ antibodies are mainly directed to the denatured protein," Autoimmunity, vol. 14, no. 1, pp. 57-65, 1992.

[85] G. Boire and J. Craft, "Biochemical and immunological heterogeneity of the Ro ribonucleoprotein particles. Analysis with sera specific for the Ro(hY5) particle," The Journal of Clinical Investigation, vol. 84, no. 1, pp. 270-279, 1989.

[86] G. Boire, F. J. Lopez-Longo, S. Lapointe, and H. A. Menard, "Sera from patients with autoimmune disease recognize conformational determinants on the $60-\mathrm{kd} \mathrm{Ro/SS}$-A protein," Arthritis and Rheumatism, vol. 34, no. 6, pp. 722-730, 1991.

[87] Y. Itoh, K. Itoh, M. B. Frank, and M. Reichlin, "Autoantibodies to the Ro/SSA autoantigen are conformation dependent II: antibodies to the denatured form of $52 \mathrm{kD}$ Ro/SSA are a cross reacting subset of antibodies to the native $60 \mathrm{kD} \mathrm{Ro/SSA}$ molecule," Autoimmunity, vol. 14, no. 2, pp. 89-95, 1993.

[88] T. Dörner, E. Feist, A. Wagenmann et al., "Anti-52 kDa Ro(SSA) autoantibodies in different autoimmune diseases preferentially recognize epitopes on the central region of the antigen," The Journal of Rheumatology, vol. 23, no. 3, pp. 462468, 1996.

[89] T. Fukuda-Kamitani and T. Kamitani, "Ubiquitination of Ro52 autoantigen," Biochemical and Biophysical Research Communications, vol. 295, no. 4, pp. 774-778, 2002.

[90] M. T. McClain, L. D. Heinlen, G. J. Dennis, J. Roebuck, J. B. Harley, and J. A. James, "Early events in lupus humoral autoimmunity suggest initiation through molecular mimicry," Nature Medicine, vol. 11, no. 1, pp. 85-89, 2005.

[91] A. Doria, M. Canova, M. Tonon et al., "Infections as triggers and complications of systemic lupus erythematosus," Autoimmunity Reviews, vol. 8, no. 1, pp. 24-28, 2008.

[92] B. D. Poole, A. K. Templeton, J. M. Guthridge, E. J. Brown, J. B. Harley, and J. A. James, "Aberrant epstein-barr viral infection in systemic lupus erythematosus," Autoimmunity Reviews, vol. 8, no. 4, pp. 337-342, 2009.

[93] F. Topfer, T. Gordon, and J. Mccluskey, "Intra- and intermolecular spreading of autoimmunity involving the nuclear self-antigens La (SS-B) and Ro (SS-A)," Proceedings of the National Academy of Sciences of the United States of America, vol. 92, no. 3, pp. 875-879, 1995.

[94] F. Furukawa, M. Kashihara-Sawami, M. B. Lyons, and D. A. Norris, "Binding of antibodies to the extractable nuclear antigens SS-A/Ro and SS-B/La is induced on the surface of human keratinocytes by ultraviolet light (UVL): implications for the pathogenesis of photosensitive cutaneous lupus," Journal of Investigative Dermatology, vol. 94, no. 1, pp. 77-85, 1990.

[95] T. D. Golan, K. B. Elkon, A. E. Gharavi, and J. G. Krueger, "Enhanced membrane binding of autoantibodies to cultured keratinocytes of systemic lupus erythematosus patients after ultraviolet B/ultraviolet a irradiation," The Journal of Clinical Investigation, vol. 90, no. 3, pp. 1067-1076, 1992. 
[96] W. P. LeFeber, D. A. Norris, S. R. Ryan et al., "Ultraviolet light induces binding of antibodies to selected nuclear antigens on cultured human keratinocytes," The Journal of Clinical Investigation, vol. 74, no. 4, pp. 1545-1551, 1984.

[97] J. Saegusa, S. Kawano, M. Koshiba et al., "Oxidative stress mediates cell surface expression of SS-A/Ro antigen on keratinocytes," Free Radical Biology and Medicine, vol. 32, no. 10, pp. 1006-1016, 2002.

[98] T. Dorner, M. Hucko, W. J. Mayet, U. Trefzer, G. R. Burmester, and F. Hiepe, "Enhanced membrane expression of the $52 \mathrm{kDa} \mathrm{Ro}(\mathrm{SS}-\mathrm{A})$ and $\mathrm{La}(\mathrm{SS}-\mathrm{B})$ antigens by human keratinocytes induced by TNF $\alpha$," Annals of the Rheumatic Diseases, vol. 54, no. 11, pp. 904-909, 1995.

[99] C. Baboonian, P. J. W. Venables, J. Booth, D. G. Williams, L. M. Roffe, and R. N. Maini, "Virus infection induces redistribution and membrane localization of the nuclear antigen La (SS-B): a possible mechanism for autoimmunity," Clinical and Experimental Immunology, vol. 78, no. 3, pp. 454-459, 1989.

[100] F. Furukawa, M. B. Lyons, L. A. Lee, S. N. Coulter, and D. A. Norris, "Estradiol enhances binding to cultured human keratinocytes of antibodies specific for SS-A/Ro and SS-B/La. Another possible mechanism for estradiol influence of lupus erythematosus," The Journal of Immunology, vol. 141, no. 5, pp. 1480-1488, 1988.

[101] L. A. Casciola-Rosen, G. Anhalt, and A. Rosen, "Autoantigens targeted in systemic lupus erythematosus are clustered in two populations of surface structures on apoptotic keratinocytes," Journal of Experimental Medicine, vol. 179, no. 4, pp. 1317-1330, 1994.

[102] J. G. Routsias and A. G. Tzioufas, "Autoimmune response and target autoantigens in Sjogren's syndrome," European Journal of Clinical Investigation, vol. 40, no. 11, pp. 1026-1036, 2010.

[103] R. W. Wilson, T. T. Provost, and W. B. Bias, "Sjogren's syndrome. Influence of multiple HLA-D region alloantigens on clinical and serologic expression," Arthritis and Rheumatism, vol. 27, no. 11, pp. 1245-1253, 1984.

[104] R. G. Hamilton, J. B. Harley, W. B. Bias et al., "Two Ro (SS-A) autoantibody responses in systemic lupus erythematosus: correlation of HLA-DR/DQ specificities with quantitative expression of Ro (SS-A) autoantibody," Arthritis and Rheumatism, vol. 31, no. 4, pp. 496-505, 1988.

[105] J. E. Gottenberg, M. Busson, P. Loiseau et al., "In primary Sjögren's syndrome, HLA class II is associated exclusively with autoantibody production and spreading of the autoimmune response," Arthritis and Rheumatism, vol. 48, no. 8, pp. 2240-2245, 2003.

[106] J. B. Harley, M. Reichlin, and F. C. Arnett Jr., "Gene interaction at HLA-DQ enhances autoantibody production in primary Sjogren's syndrome," Science, vol. 232, no. 4754, pp. 1145-1147, 1986.

[107] J. D. Reveille, M. J. Macleod, K. Whittington, and F. C. Arnett Jr., "Specific amino acid residues in the second hypervariable region of HLA-DQA1 and DQB1 chain genes promote the Ro (SS-A)/La (SS-B) autoantibody responses," The Journal of Immunology, vol. 146, no. 11, pp. 3871-3876, 1991.

[108] I. Peene, L. Meheus, S. De Keyser, R. Humbel, E. M. Veys, and F. De Keyser, "Anti-Ro52 reactivity is an independent and additional serum marker in connective tissue disease," Annals of the Rheumatic Diseases, vol. 61, no. 10, pp. 929-933, 2002.

[109] D. M. Langguth, S. Morris, L. Clifford et al., "Specific testing for "isolated" anti-52 kDa SSA/Ro antibodies during standard anti-extractable nuclear antigen testing is of limited clinical value," Journal of Clinical Pathology, vol. 60, no. 6, pp. 670-673, 2007.

[110] B. Rozman, B. Bozic, M. Kos-Golja, M. Plesivcnik-Novljan, and T. Kveder, "Immunoserological aspects of idiopathic inflammatory muscle disease," Wiener Klinische Wochenschrift, vol. 112, no. 15-16, pp. 722-727, 2000.

[111] R. Brouwer, G. J. D. Hengstman, W. Vree Egberts et al., "Autoantibody profiles in the sera of European patients with myositis," Annals of the Rheumatic Diseases, vol. 60, no. 2, pp. 116-123, 2001.

[112] M. Koenig, M. J. Fritzler, I. N. Targoff, Y. Troyanov, and J. L. Senécal, "Heterogeneity of autoantibodies in 100 patients with autoimmune myositis: insights into clinical features and outcomes," Arthritis Research and Therapy, vol. 9, no. 4, article R78, 2007.

[113] V. Eyraud, O. Chazouilleres, E. Ballot, C. Corpechot, R. Poupon, and C. Johanet, "Significance of antibodies to soluble liver antigen/liver pancreas: a large French study," Liver International, vol. 29, no. 6, pp. 857-864, 2009.

[114] F. Franceschini and I. Cavazzana, "Anti-Ro/SSA and La/SSB antibodies," Autoimmunity, vol. 38, no. 1, pp. 55-63, 2005.

[115] P. J. Maddison, T. T. Provost, and M. Reichlin, "Serological findings in patients with 'ANA-negative' systemic lupus erythematosus," Medicine, vol. 60, no. 2, pp. 87-94, 1981.

[116] T. T. Provost, F. C. Arnett Jr., and M. Reichlin, "Homozygous C2 deficiency, lupus erythematosus, and anti-Ro (SSA) antibodies," Arthritis and Rheumatism, vol. 26, no. 10, pp. 1279-1282, 1983.

[117] G. Tappeiner, H. Hintner, and S. Scholz, "Systemic lupus erythematosus in hereditary deficiency of the fourth component of complement," Journal of the American Academy of Dermatology, vol. 7, no. 1, pp. 66-79, 1982.

[118] T. T. Provost, N. Talal, J. B. Harley, M. Reichlin, and E. Alexander, "The relationship between anti-Ro (SS-A) antibody-positive Sjogren's syndrome and anti-Ro (SS-A) antibody-positive lupus erythematosus," Archives of Dermatology, vol. 124, no. 1, pp. 63-71, 1988.

[119] J. P. Buyon, R. J. Winchester, S. G. Slade et al., "Identification of mothers at risk for congenital heart block and other neonatal lupus syndromes in their children: comparison of enzyme-linked immunosorbent assay and immunoblot for measurement of anti-SS-A/Ro and anti- SS-B/La antibodies," Arthritis and Rheumatism, vol. 36, no. 9, pp. 1263-1273, 1993.

[120] J. P. Buyon, R. M. Clancy, and D. M. Friedman, "Cardiac manifestations of neonatal lupus erythematosus: guidelines to management, integrating clues from the bench and bedside," Nature Clinical Practice Rheumatology, vol. 5, no. 3, pp. 139-148, 2009.

[121] M. D. Lockshin, E. Bonfa, K. Elkon, and M. L. Druzin, "Neonatal lupus risk to newborns of mothers with systemic lupus erythematosus," Arthritis and Rheumatism, vol. 31, no. 6, pp. 697-701, 1988.

[122] S. Garcia, J. H. M. Nascimento, E. Bonfa et al., "Cellular mechanism of the conduction abnormalities induced by serum from anti-Ro/SSA-positive patients in rabbit hearts," The Journal of Clinical Investigation, vol. 93, no. 2, pp. 718724, 1994.

[123] O. Meyer, G. Hauptmann, and G. Tappeiner, "Genetic deficiency of C4, C2 or C1q and lupus syndromes. Association with anti-Ro (SS-A) antibodies," Clinical and Experimental Immunology, vol. 62, no. 3, pp. 678-684, 1985.

[124] M. R. Arbuckle, M. T. McClain, M. V. Rubertone et al., "Development of autoantibodies before the clinical onset of 
systemic lupus erythematosus," The New England Journal of Medicine, vol. 349, no. 16, pp. 1526-1533, 2003.

[125] C. Eriksson, H. Kokkonen, M. Johansson, G. Hallmans, G. Wadell, and S. Rantapää-Dahlqvist, "Autoantibodies predate the onset of systemic lupus erythematosus in northern Sweden," Arthritis Research and Therapy, vol. 13, no. 1, article R30, 2011.

[126] L. J. Catoggio, R. P. Skinner, G. Smith, and P. J. Maddison, "Systemic lupus erythematosus in the elderly: clinical and serological characteristics," The Journal of Rheumatology, vol. 11, no. 2, pp. 175-181, 1984.

[127] S. Praprotnik, B. Bozic, T. Kveder, and B. Rozman, "Fluctuation of anti-Ro/SS-A antibody levels in patients with systemic lupus erythematosus and Sjogren's syndrome: a prospective study," Clinical and Experimental Rheumatology, vol. 17, no. 1, pp. 63-68, 1999.

[128] E. Scopelitis, J. J. Biundo, and M. A. Alspaugh, "Anti-SS-A antibody and other antinuclear antibodies in systemic lupus erythematosus," Arthritis and Rheumatism, vol. 23, no. 3, pp. 287-293, 1980.

[129] R. H. W. M. Derksen and J. F. Meilof, "Anti-Ro/SS-A and anti-La/SS-B autoantibody levels in relation to systemic lupus erythematosus disease activity and congenital heart block: a longitudinal study comprising two consecutive pregnancies in a patient with systemic lupus erythematosus," Arthritis and Rheumatism, vol. 35, no. 8, pp. 953-959, 1992.

[130] M. Wahren, P. Tengnér, I. Gunnarsson et al., "Ro/SS-A and La/SS-B antibody level variation in patients with Sjogren's syndrome and systemic lupus erythematosus," Journal of Autoimmunity, vol. 11, no. 1, pp. 29-38, 1998.

[131] A. B. Hassan, I. E. Lundberg, D. Isenberg, and M. WahrenHerlenius, "Serial analysis of Ro/SSA and La/SSB antibody levels and correlation with clinical disease activity in patients with systemic lupus erythematosus," Scandinavian Journal of Rheumatology, vol. 31, no. 3, pp. 133-139, 2002.

[132] P. Maddison, H. Mogavero, T. T. Provost, and M. Reichlin, "The clinical significance of autoantibodies to a soluble cytoplasmic antigen in systemic lupus erythematosus and other connective tissue diseases," The Journal of Rheumatology, vol. 6, no. 2, pp. 189-195, 1979.

[133] E. Simmons-O’Brien, S. Chen, R. Watson et al., "One hundred anti-Ro (SS-A) antibody positive patients: a 10-year follow-up," Medicine, vol. 74, no. 3, pp. 109-130, 1995.

[134] A. Brucato, R. Cimaz, R. Caporali, V. Ramoni, and J. Buyon, "Pregnancy outcomes in patients with autoimmune diseases and anti-Ro/SSA antibodies," Clinical Reviews in Allergy and Immunology, vol. 40, no. 1, pp. 27-41, 2011.

[135] L. Chameides, R. C. Truex, V. Vetter, W. J. Rashkind, F. M. Galioto Jr., and J. A. Noonan, "Association of maternal systemic lupus erythematosus with congenital complete heart block," The New England Journal of Medicine, vol. 297, no. 22, pp. 1204-1207, 1977.

[136] W. L. Weston, C. Harmon, and C. Peebles, "A serological marker for neonatal lupus erythematosus," British Journal of Dermatology, vol. 107, no. 4, pp. 377-382, 1982.

[137] L. A. Lee, W. B. Bias, F. C. Arnett Jr. et al., "Immunogenetics of the neonatal lupus syndrome," Annals of Internal Medicine, vol. 99, no. 5, pp. 592-596, 1983.

[138] R. Claus, H. Hickstein, T. Külz et al., "Identification and management of fetuses at risk for, or affected by, congenital heart block associated with autoantibodies to SSA (Ro), SSB (La), or an HsEg5-like autoantigen," Rheumatology International, vol. 26, no. 10, pp. 886-895, 2006.
[139] M. Fujimoto, M. Shimozuma, N. Yazawa et al., "Prevalence and clinical relevance of $52-\mathrm{kDa}$ and $60-\mathrm{kDa}$ Ro/SS-A autoantibodies in Japanese patients with systemic sclerosis," Annals of the Rheumatic Diseases, vol. 56, no. 11, pp. 667-670, 1997.

[140] M. B. Frank, V. McCubbin, E. Trieu, Y. Wu, D. A. Isenberg, and I. N. Targoff, "The association of anti-Ro52 autoantibodies with myositis and scleroderma autoantibodies," Journal of Autoimmunity, vol. 12, no. 2, pp. 137-142, 1999.

[141] I. N. Targoff, F. W. Miller, T. A. Medsger Jr., and C. V. Oddis, "Classification criteria for the idiopathic inflammatory myopathies," Current Opinion in Rheumatology, vol. 9, no. 6, pp. 527-535, 1997.

[142] A. H. Kao, D. Lacomis, M. Lucas, N. Fertig, and C. V. Oddis, "Anti-signal recognition particle autoantibody in patients with and patients without idiopathic inflammatory myopathy," Arthritis and Rheumatism, vol. 50, no. 1, pp. 209215, 2004.

[143] E. Schneeberger, G. Citera, M. Heredia, and J. M. Cocco, "Clinical significance of anti-Ro antibodies in rheumatoid arthritis," Clinical Rheumatology, vol. 27, no. 4, pp. 517-519, 2008.

[144] H. M. Moutsopoulos, H. Giotaki, P. J. Maddison, A. C. Mavridis, A. A. Drosos, and F. N. Skopouli, "Antibodies to cellular antigens in Greek patients with autoimmune rheumatic diseases: anti-Ro (SSA) antibody a possible marker of penicillamine-D intolerance," Annals of the Rheumatic Diseases, vol. 43, no. 2, pp. 285-287, 1984.

[145] H. M. Moutsopoulos, F. N. Skopouli, A. K. Sarras et al., "AntiRo(SSA) positive rheumatoid arthritis (RA): a clinicoserological group of patients with high incidence of D-penicillamine side effects," Annals of the Rheumatic Diseases, vol. 44, no. 4, pp. 215-219, 1985.

[146] M. Tishler, B. Golbrut, Y. Shoenfeld, and M. Yaron, "AntiRo(SSA) antibodies in patients with rheumatoid arthritis a possible marker for gold induced side effects," The Journal of Rheumatology, vol. 21, no. 6, pp. 1040-1042, 1994.

[147] R. Matsudaira, N. Tamura, F. Sekiya, M. Ogasawara, K. Yamanaka, and Y. Takasaki, "Anti-Ro/SSA antibodies are an independent factor associated with an insufficient response to tumor necrosis factor inhibitors in patients with rheumatoid arthritis," The Journal of Rheumatology, vol. 38, no. 11, pp. 2346-2354, 2011.

[148] D. A. Norris, "Pathomechanisms of photosensitive lupus erythematosus," Journal of Investigative Dermatology, vol. 100, no. 1, pp. 58S-68S, 1993.

[149] D. Ioannides, B. D. Golden, J. P. Buyon, and J. C. Bystryn, "Expression of SS-A/Ro and SS-B/La antigens in skin biopsy specimens of patients with photosensitive forms of lupus erythematosus," Archives of Dermatology, vol. 136, no. 3, pp. 340-346, 2000.

[150] R. D. Sontheimer, "Photoimmunology of lupus erythematosus and dermatomyositis: a speculative review," Photochemistry and Photobiology, vol. 63, no. 5, pp. 583-594, 1996.

[151] J. S. Deng, L. W. Bair Jr., S. Shen-Schwarz, R. RamseyGoldman, and T. Medsger Jr., "Localization of Ro (SS-A) antigen in the cardiac conduction system," Arthritis and Rheumatism, vol. 30, no. 11, pp. 1232-1238, 1987.

[152] P. V. Taylor, J. S. Scott, L. M. Gerlis, E. Esscher, and O. Scott, "Maternal antibodies against fetal cardiac antigens in congenital complete heart block," The New England Journal of Medicine, vol. 315, no. 11, pp. 667-672, 1986. 
[153] C. E. Tseng and J. P. Buyon, "Neonatal lupus syndromes," Rheumatic Disease Clinics of North America, vol. 23, no. 1, pp. 31-54, 1997.

[154] R. M. Clancy, P. J. Neufing, P. Zheng et al., "Impaired clearance of apoptotic cardiocytes is linked to anti-SSA/Ro and -SSB/La antibodies in the pathogenesis of congenital heart block," The Journal of Clinical Investigation, vol. 116, no. 9, pp. 2413-2422, 2006.

[155] P. Briassouli, E. V. Komissarova, R. M. Clancy, and J. P. Buyon, "Role of the urokinase plasminogen activator receptor in mediating impaired efferocytosis of anti-SSA/Robound apoptotic cardiocytes implications in the pathogenesis of congenital heart block," Circulation Research, vol. 107, no. 3, pp. 374-387, 2010.

[156] P. Briassouli, D. Rifkin, R. M. Clancy, and J. P. Buyon, "Binding of anti-SSA antibodies to apoptotic fetal cardiocytes stimulates urokinase plasminogen activator (uPA)/uPA receptor-dependent activation of TGF-beta and potentiates fibrosis," The Journal of Immunology, vol. 187, no. 10, pp. 5392-5401, 2011.

[157] P. E. Lazzerini, M. Acampa, F. Guideri et al., "Prolongation of the corrected QT interval in adult patients with AntiRo/SSA-positive connective tissue diseases," Arthritis and Rheumatism, vol. 50, no. 4, pp. 1248-1252, 2004.

[158] J. Bourre-Tessier, A. E. Clarke, T. Huynh et al., "Prolonged corrected QT interval in anti-Ro/SSA-positive adults with systemic lupus erythematosus," Arthritis Care and Research, vol. 63, no. 7, pp. 1031-1037, 2011.

[159] P. E. Lazzerini, P. L. Capecchi, M. Acampa et al., "Arrhythmogenic effects of anti-Ro/SSA antibodies on the adult heart: more than expected?" Autoimmunity Reviews, vol. 9, no. 1, pp. 40-44, 2009.

[160] P. E. Lazzerini, P. L. Capecchi, F. Guideri et al., "Comparison of frequency of complex ventricular arrhythmias in patients with positive versus negative anti-Ro/SSA and connective tissue disease," American Journal of Cardiology, vol. 100, no. 6, pp. 1029-1034, 2007.

[161] D. L. Mallery, W. A. McEwan, S. R. Bidgood, G. J. Towers, C. M. Johnson, and L. C. James, "Antibodies mediate intracellular immunity through tripartite motif-containing 21 (TRIM21)," Proceedings of the National Academy of Sciences of the United States of America, vol. 107, no. 46, pp. 1998519990, 2010.

[162] A. Espinosa, J. Hennig, A. Ambrosi et al., "Anti-Ro52 autoantibodies from patients with Sjogren's syndrome inhibit the Ro52 E3 ligase activity by blocking the E3/E2 interface," The Journal of Biological Chemistry, vol. 286, no. 42, pp. 36478 36491, 2011. 


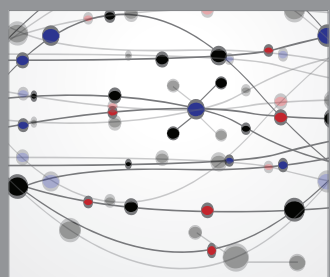

The Scientific World Journal
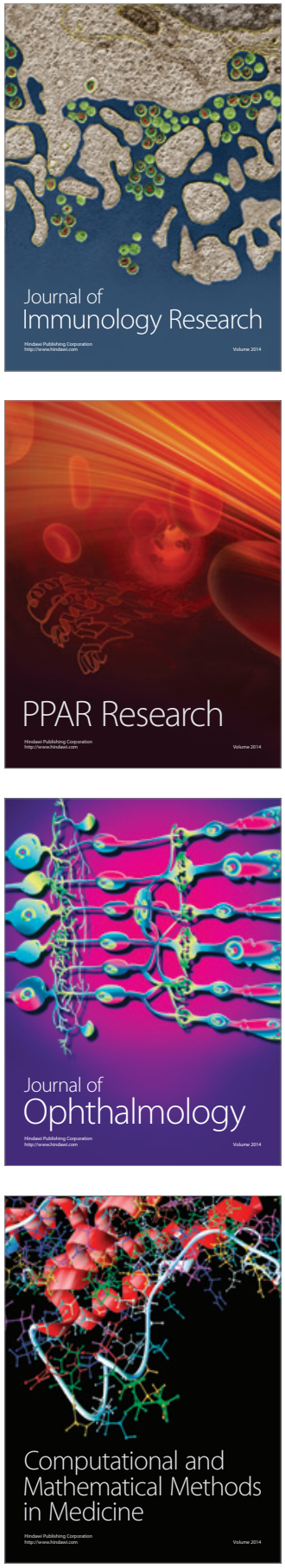

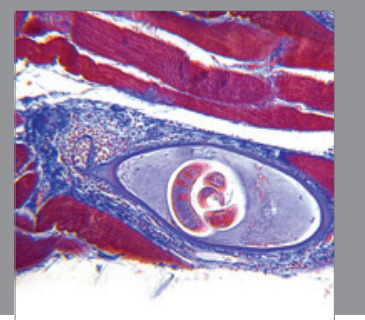

Gastroenterology

Research and Practice
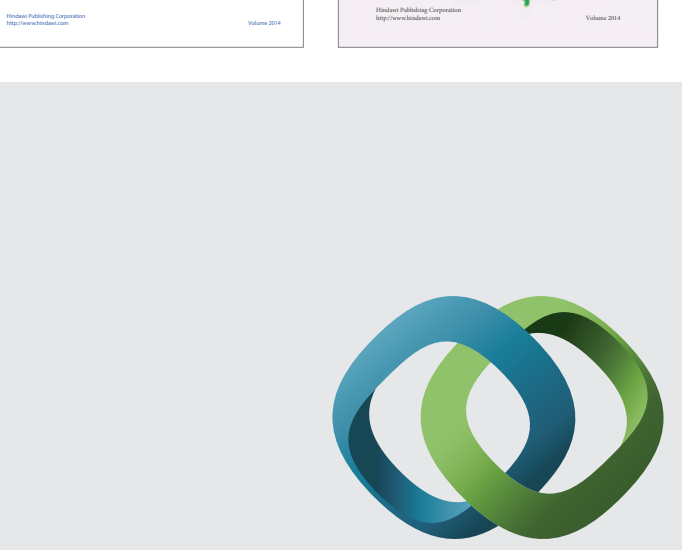

\section{Hindawi}

Submit your manuscripts at

http://www.hindawi.com
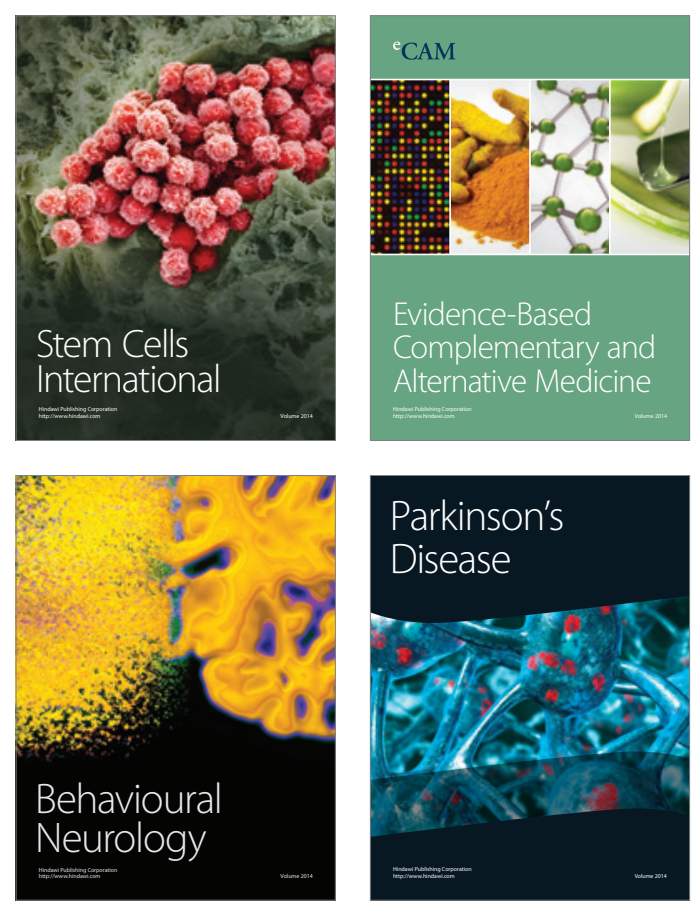

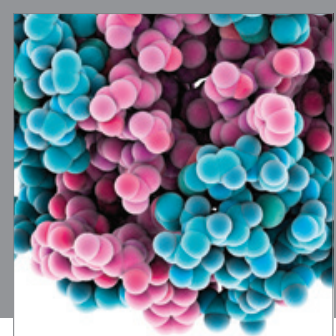

Journal of
Diabetes Research

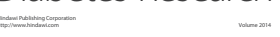

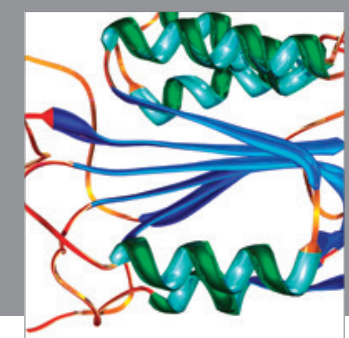

Disease Markers
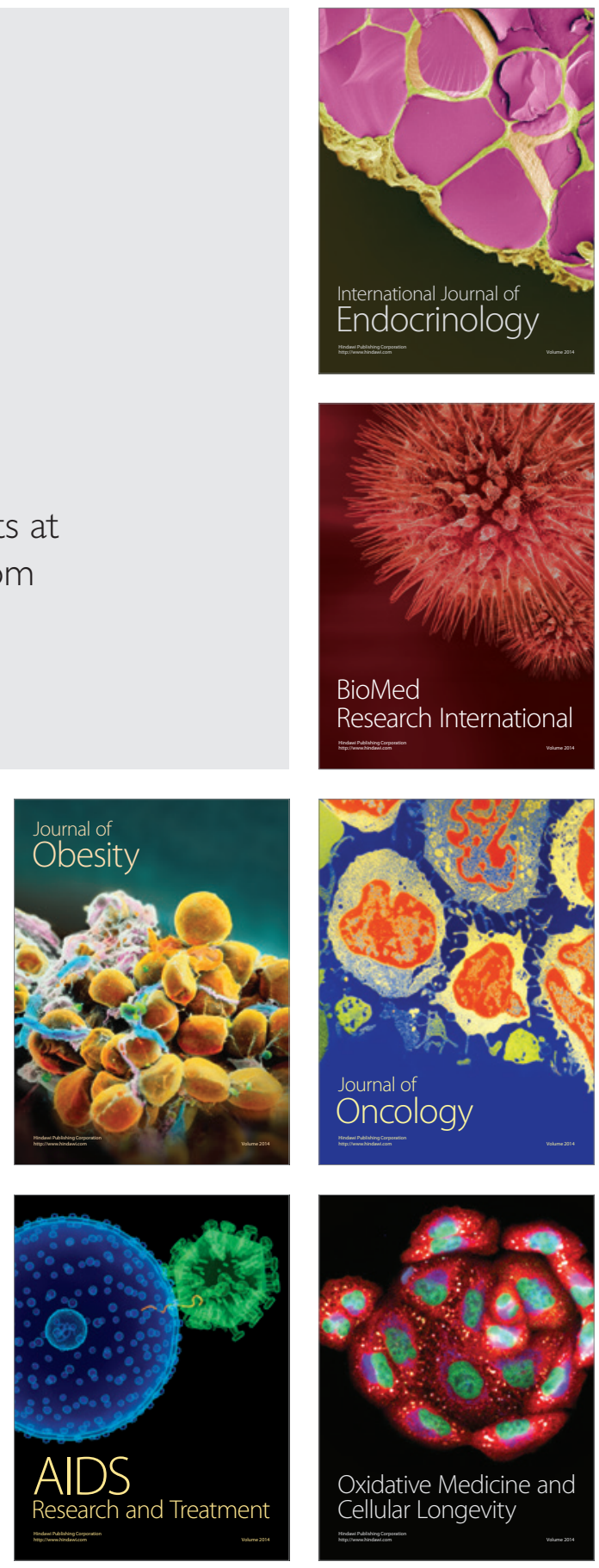